https://doi.org/10.48009/1_iis_2005_238-243

\title{
STUDENTS' ACTIVITY PREFERENCES IN WEB-BASED DISTANCE LEARNING COURSES: A BUSINESS SCHOOL'S EXPERIENCES
}

\author{
Donald R. Moscato, Hagan School of Business, Iona College, dmoscato@iona.edu \\ Eric D. Moscato, Hagan School of Business, Iona College, emoscato@iona.edu
}

\begin{abstract}
As part of a college-wide initiative on the assessment of learning that is an integral component of all AACSB-accredited program evaluations, the authors explored the activity patterns of students that enrolled in Web-based distance learning courses[7]. The field study consisted of 68 courses conducted at an AACSB-accredited business school. The classes represented both graduate and undergraduate programs. All classes were offered in the pure distance learning mode and none were offered in the web-enhanced, blended or hybrid format. The college employs the Blackboard course container system as its infrastructure to support its distance learning initiative. Data was analyzed regarding preferences for time of day usage of the Blackboard system, day of week preferences and specific component area preferences of the course container system. The results of the study raise interesting questions regarding students' preferences.
\end{abstract}

Keywords: Distance learning, students' preferences, Blackboard, activity levels

\section{INTRODUCTION}

Faculty teaching Web-based distance learning courses design their courses with certain assumptions and expectations about how their students will allocate their time and energy in mastering the subject matter over the course of the semester, trimester or quarter systems [7]. There are certain heuristics that are advanced regarding how much out-of-class time should be devoted to the course of study in addition to regular class time, recitation sessions or lab experiences [10]. The stark truth is that at the end of the term instructors have very little knowledge of how the students spent their time in the pursuit of knowledge [9]. They only know the final student performance via an assessment tool(s). At best, they have anecdotal evidence of how, when and where they spent their time $[1,2]$. While this state of affairs might be acceptable to some, others might benefit from feedback regarding information about what days they worked, what time of day they devoted to class work and what specific activities were used in the learning process to satisfy the course requirements. In this study we explored certain hypotheses that would help us understand how students used the functionality of a popular course container system and, in so doing, to increase our understanding of the behavior of our students when utilizing these systems.

\section{METHOD}

The research study was conducted at an AACSB-accredited college of business. Over 68 Webbased distance learning courses were used in the study. The courses were given at both the graduate and undergraduate divisions. The courses were given over a four year period by several different professors some of whom taught courses at both of the levels under study. The nature of the college's distance learning program is such that all students in the study were also local to the 
area. In other words, there was geographical homogeneity present in all of the data. For example, no courses were being conducted with some students in Asia while others were located in the U.S. or Europe. This fact is important since different time zones would influence the results of the study.

Data were accumulated by the Course Statistics feature of the Blackboard course container system during the existence of each course. This database was then analyzed as the basis for the findings that are being reported. Faculty gave permission for the researchers to have access to the course statistics that were accumulated.

Data were analyzed using t tests for the comparison of the means of the students' activity levels between two divisions-graduate and undergraduate. Tests of statistical significance were completed and the $\mathrm{p}$ values reported [6]. With the three research questions data are presented for all of the courses so as to convey the central tendency and variability across all depicted areas under analysis.

\section{RESEARCH QUESTIONS}

This study explored the following hypotheses:

1. There is no difference between graduate and undergraduate students in the days of the week that they used the course container system.

2. There is no difference between graduate and undergraduate students in the times of the day that they used the course container system.

3. There is no difference between graduate and undergraduate students in the preference for the use of specific components of the course container system.

Additionally, the following questions were posed and analyzed:

1. What were the activity levels of all students by day of the week?

2. What were the activity levels by time of day for all students?

3. What were the activity levels by specific functionality for all students?

\section{RESULTS}

\section{Hypothesis One}

Table 1 presents the results of the comparison of activity by day of the week along with the statistical significance. The results indicate that only on Sunday, Thursday and Friday is there any difference between graduate and undergraduate students' use of the system and that is at the 
one-tail test at the 0.05 level of significance. On the other days there was no difference in activity between graduate and undergraduate students activity levels.

Table 1. Difference Between Means (Graduate vs. Undergraduate) - Day of the Week

\begin{tabular}{lcccccc}
\multicolumn{1}{c}{ Day } & t value & $\begin{array}{c}\text { t-critical } \\
\text { 2 tail test }\end{array}$ & P value & $\begin{array}{c}\text { t critical } \\
\text { 1 tail test }\end{array}$ & P value & $\begin{array}{c}\text { Significant } \\
\text { at .05 }\end{array}$ \\
\hline Sunday & 1.823 & 2.002 & .070 & 1.672 & .037 & 1 tail only \\
Monday & 1.167 & 2.002 & .248 & 1.672 & .124 & No \\
Tuesday & 0.212 & 2.002 & .833 & 1.672 & .416 & No \\
Wednesday & -0.618 & 2.002 & .539 & 1.672 & .269 & No \\
Thursday & -1.695 & 2.002 & .095 & 1.672 & .048 & 1 tail only \\
Friday & -1.704 & 2.002 & .094 & 1.672 & .047 & 1 tail only \\
Saturday & 0.951 & 2.002 & .345 & 1.672 & .173 & No
\end{tabular}

\section{Hypothesis Two}

Table 2 presents the results of the comparison of time of the day along with the statistical significance. The results indicate that of the times studied, only at 2:00 pm was there a difference between the graduate and undergraduate student activity. The significance was at the one tail level. The other times of the day were not included because they had very little activity in both levels. Essentially, the results indicate that graduate and undergraduate students used the container at the same scheduled hours.

Table 2. Difference Between Means (Graduate vs. Undergraduate) - Time of the Day

\begin{tabular}{ccccccc}
$\begin{array}{c}\text { Hour of } \\
\text { Day }\end{array}$ & t value & $\begin{array}{c}\text { t-critical } \\
\text { 2 tail test }\end{array}$ & P value & $\begin{array}{c}\text { t critical } \\
\text { 1 tail test }\end{array}$ & P value & $\begin{array}{c}\text { Significant } \\
\text { at .05 }\end{array}$ \\
\hline $\mathbf{2} \mathbf{~ p m}$ & -1.715 & 2.002 & .092 & 1.672 & .046 & 1 tail only \\
$\mathbf{3} \mathbf{~ p m}$ & 0.020 & 2.002 & .984 & 1.672 & .492 & No \\
$\mathbf{4} \mathbf{~ p m}$ & -0.238 & 2.002 & .813 & 1.672 & .406 & No \\
$\mathbf{5} \mathbf{~ p m}$ & 0.740 & 2.002 & .462 & 1.672 & .231 & No \\
$\mathbf{6} \mathbf{~ p m}$ & 0.050 & 2.002 & .960 & 1.672 & .480 & No \\
$\mathbf{7} \mathbf{~ p m}$ & -0.377 & 2.002 & .708 & 1.672 & .354 & No \\
$\mathbf{8} \mathbf{~ p m}$ & 0.515 & 2.002 & .609 & 1.672 & .304 & No \\
$\mathbf{9} \mathbf{~ p m}$ & -0.074 & 2.002 & .941 & 1.672 & .471 & No \\
$\mathbf{1 0} \mathbf{~ p m}$ & 1.651 & 2.002 & .104 & 1.672 & .052 & No \\
$\mathbf{1 1} \mathbf{~ p m}$ & -0.301 & 2.002 & .764 & 1.672 & .382 & No
\end{tabular}

\section{Hypothesis Three}

Table 3 presents the results of the comparison of the different components within the Blackboard course container system along with the statistical significance. The results indicate there was a difference between the graduate and undergraduate students in the use of the Content section and that was only at the one-tail test. However, there was a strong significance regarding the Tools 
component. The two groups used the Tools differently. There was no difference in the activity levels within the other components.

Table 3. Difference Between Means (Graduate vs Undergraduate)-Course Container Component

\begin{tabular}{lcccccc}
\multicolumn{1}{c}{ Component } & t value & $\begin{array}{c}\text { t-critical } \\
\mathbf{2} \text { tail test }\end{array}$ & P value & $\begin{array}{c}\text { t critical } \\
\text { 1 tail test }\end{array}$ & P value & $\begin{array}{c}\text { Significant } \\
\text { at .05 }\end{array}$ \\
\hline Content & -1.787 & 2.002 & .079 & 1.672 & .040 & 1 tail only \\
Tools & -3.702 & 2.002 & .000 & 1.672 & .000 & Yes \\
Discussion Board & 1.509 & 2.002 & .137 & 1.672 & .068 & No \\
Digital Drop Box & -1.089 & 2.002 & .281 & 1.672 & .140 & No \\
Group & -0.173 & 2.002 & .863 & 1.672 & .432 & No \\
Announcements- & -0.855 & 2.002 & .396 & 1.672 & .198 & No \\
Residual & 0.274 & 2.002 & .785 & 1.672 & .393 & No
\end{tabular}

\section{Question One}

Table 4 presents the summary measures of central tendency (mean percentages) and variation for each day of the week for all of the courses in the study. The smaller the coefficient of variation, the less variability there is in the day of the week across all courses. Observe that both Sunday and Friday exhibit the greatest degree of variation. A plausible explanation could be that professors set due dates that are targeted to these days of the week.

Table 4. Descriptive Statistics of Days of the Week for All Courses

\begin{tabular}{lccc} 
Day of the Week & Mean & Standard Deviation & $\begin{array}{c}\text { Coefficient of } \\
\text { Variation }\end{array}$ \\
\hline Sunday & 13.29 & 6.62 & 0.50 \\
Monday & 17.09 & 4.8 & 0.28 \\
Tuesday & 15.26 & 4.05 & 0.27 \\
Wednesday & 14.72 & 3.3 & 0.22 \\
Thursday & 14.37 & 3.02 & 0.21 \\
Friday & 15.10 & 8.17 & 0.54 \\
Saturday & 10.13 & 3.76 & 0.37
\end{tabular}

\section{Question Two}

Table 5 presents the summary measures of central tendency and variation for selected times of the day for all courses in the study. From the data, it appears that there is greater variation in the evening hours. This could reflect different lifestyles of graduate and undergraduate students as reflected in their use of the course container. 
Table 5. Descriptive Statistics of Times of the Day for All Courses

\begin{tabular}{cccc} 
Time of Day & Mean & Standard Deviation & $\begin{array}{c}\text { Coefficient of } \\
\text { Variation }\end{array}$ \\
\hline $\mathbf{2} \mathbf{~ p m}$ & 6.57 & 1.05 & 0.16 \\
$\mathbf{3} \mathbf{~ p m}$ & 6.33 & 1.10 & 0.17 \\
$\mathbf{4} \mathbf{~ p m}$ & 6.21 & 1.24 & 0.20 \\
$\mathbf{5} \mathbf{~ p m}$ & 6.08 & 1.27 & 0.21 \\
$\mathbf{6} \mathbf{~ p m}$ & 5.29 & 1.66 & 0.31 \\
$\mathbf{7} \mathbf{~ p m}$ & 5.58 & 1.79 & 0.32 \\
$\mathbf{8} \mathbf{~ p m}$ & 6.48 & 1.63 & 0.25 \\
$\mathbf{9} \mathbf{~ p m}$ & 6.80 & 1.85 & 0.27 \\
$\mathbf{1 0} \mathbf{~ p m}$ & 6.39 & 1.99 & 0.31 \\
$\mathbf{1 1} \mathbf{~ p m}$ & 4.18 & 1.21 & 0.29
\end{tabular}

\section{Question Three}

Table 6 depicts the activity levels of the selected components of the Blackboard course container as employed by students in all of the courses in the study. The category labeled Residual is a calculated amount based upon the difference between 100 and the sum of the other listed components. Only the Discussion Board component had a reasonable level of variability indicating that the other components varied greatly in terms of usage among the students in all of the courses.

Table 6. Descriptive Statistics of Container Component Activity Levels for All Courses

\begin{tabular}{lccc}
$\begin{array}{c}\text { Course Container } \\
\text { Component }\end{array}$ & Mean & Standard Deviation & $\begin{array}{c}\text { Coefficient of } \\
\text { Variation }\end{array}$ \\
\hline Content & 8.97 & 6.37 & 0.71 \\
Tools & 3.36 & 1.56 & 0.46 \\
Discussion Board & 69.28 & 13.35 & 0.19 \\
Digital Drop Box & 1.42 & 1.78 & 1.25 \\
Groups & 2.48 & 4.76 & 1.92 \\
Announcements & 6.41 & 2.65 & 0.41 \\
Residual & 8.08 & 6.11 & 0.76
\end{tabular}

\section{DISCUSSION OF RESULTS}

The results of this study shed new light on the activity preferences of both graduate and undergraduate business students in Web-based distance learning courses. Prevailing attitudes that there would be a clear difference in activity preferences between graduate and undergraduate business students was not supported by the results of this research effort. In fact, it was quite evident that both levels of students behaved in very similar and consistent patterns. It should be noted that all students in this study are taking a combination of traditional and distance learning 
courses. Both groups use distance learning as a supplement to traditional courses and not in lieu of them. Future research might investigate the activity levels of students in pure distance learning degree programs. Results might differ owing to the maturity levels of these students as demonstrated by their commitment to a total distance learning modality. Most observers note that distance learning courses are not for everyone. A distance learning student must be committed to a self-directed learning style. Students in this study demonstrated a remarkable degree of homogeneity in their activity levels of the course container system.

It is likely that an extensive Web-based DL program that spanned multiple time zones might yield a different set of results. In any case, the results of this study should give course instructors material to reflect upon as they structure future courses. Relying solely on our individual experiences could easily lead us into making incorrect assumptions on how our students spend their time while taking distance learning courses $[4,8]$. The ultimate objective is to improve student learning [5]. By knowing how students use the distance learning platform delivery system we can go a long way to designing more effective learning systems. As more research is completed on Web-based distance learning we can expect additional insights into this evolving modality [3].

\section{REFERENCES}

1. Boettcher, J. V. (November 2004). Are We There Yet? Campus Technology, 22-26.

2. Bruce, L. (2003). Standards of Excellence in Distance Education, Proceedings of Syllabus Conference 2003.

3. DiPaolo, A. (2003). Choices and Challenges: Lessons Learned in the Evolution of Online Education, Proceedings of Syllabus Conference 2003.

4. Ehrmann, S. C. and Gilbert, S. W. (July 2003). Kinds of Assessment That Can Really Help, Syllabus, 37-40.

5. Gersten, K. and Evans, L. J. (November 2004). Catalyst for Transforming the TeachingLearning Enterprise, Campus Technology, 29-32.

6. Keller, G. and Warrack, B. (1999). Statistics for Management and Economics $4^{\text {th }}$ Edition. Duxbury Press.

7. Moscato, D. R. (2003). Avoiding Pitfalls In Implementing A Web-Based Distance Learning Strategy, Communications of the IIMA, 3(3), 23-37.

8. Moscato, D. R. (2004). An Examination of Web-Based Distance Learning Assessment Styles in a College of Business:A Longitudinal Study. Issues in Information Systems, 5(1), 226-232.

9. National Education Association. (June 14, 2000). Confronting the Future of Distance Learning- Placing Quality in Reach, http://www.nea.org/nr/nr000614.html.

10. Zemke, R. (September 2002). Who Needs Learning Theory Anyway? Training, 86-91. 